\title{
Melanogenesis and Melasma Treatment
}

\author{
Adriana Solange Maddaleno ${ }^{1,2}$, Judit Camargo ${ }^{2}$, Montserrat Mitjans ${ }^{1}$ and Maria Pilar Vinardell ${ }^{1, *(\mathbb{C})}$ \\ 1 Department of Biochemistry and Physiology, Faculty of Pharmacy and Food Sciences, \\ Universitat de Barcelona, 08028 Barcelona, Spain; adrianamaddaleno@ub.edu (A.S.M.); \\ montsemitjans@ub.edu (M.M.) \\ 2 Roka Furadada S. L., Llacuna 162-164, 08018 Barcelona, Spain; judit@rokafuradada.com \\ * Correspondence: mpvinardellmh@ub.edu; Tel.: +34-934024505
}

Citation: Maddaleno, A.S.; Camargo,

J.; Mitjans, M.; Vinardell, M.P.

Melanogenesis and Melasma

Treatment. Cosmetics 2021, 8, 82 .

https://doi.org/10.3390/cosmetics

8030082

Academic Editor: Nobutomo Ikarash

Received: 27 July 2021

Accepted: 31 August 2021

Published: 2 September 2021

Publisher's Note: MDPI stays neutral with regard to jurisdictional claims in published maps and institutional affiliations.

Copyright: (c) 2021 by the authors. Licensee MDPI, Basel, Switzerland. This article is an open access article distributed under the terms and conditions of the Creative Commons Attribution (CC BY) license (https:// creativecommons.org/licenses/by/ $4.0 /)$.

\begin{abstract}
Melanocytes are highly specialised dendritic cells that transfer melanin to keratinocytes in subcellular lysosome-like organelles called melanosomes, where melanin is synthesised and stored. Melanin is a complex pigment that provides colour and photoprotection to the skin, hair, and eyes of mammals. The regulation of melanogenesis includes various mechanisms and factors including genetic, environmental, and endocrine factors. Knowledge of the pigmentation process is important not only to understand hyperpigmentation but also to design treatments and therapies to treat them. Whitening cosmetics with anti-melanogenesis activity are very popular. In the present manuscript, we review the mechanisms and the signalling pathways involved in skin pigmentation and we specifically focus on the alteration of melanogenesis that leads to melasma and results in hyperpigmentation. Finally, current therapies and treatments including topical, oral, and phototherapies are discussed and described, with a special emphasis on the cosmetics' action.
\end{abstract}

Keywords: melanin synthesis; pigmentation; melasma; MITF

\section{Introduction}

Melanin is a complex pigment that provides colour and photoprotection to the skin, hair, and eyes of mammals. Melanogenesis, the process through which melanocytes synthesise melanin, can be altered, producing pigmentary skin disorders such as melasma which result in hyperpigmentation. Melanocytes are highly specialised dendritic cells that transfer melanin to keratinocytes in subcellular lysosome-like organelles called melanosomes, where melanin is synthesised and stored. Fitzpatrick and Breathnach proposed in 1963 the "epidermal melanin unit". This concept consisted of the interaction of 1 melanocyte and approximately 36 keratinocytes to produce pigmentation. More recently, the keratinocyteLangerhans-melanocyte (KLM) unit has been proposed, which does not exclude the possibility of including other epidermal cells [1].

Several studies have suggested different mechanisms for the melanosome transfer such as cytophagocytosis, membrane fusion, shedding-phagocytosis, and exocytosis-endocytosis [2]. Melanogenesis can be regulated by genetic, environmental (ultraviolet (UV) radiation) and endocrine factors (pregnancy and ageing) [3]. Knowledge of the pigmentation process is important for designing bleaching products to treat skin hyperpigmentation.

\section{Main Signalling Pathways in Melanogenesis}

Multiple signalling pathways are involved in melanogenesis (Table 1), specifically in the regulation of the microphthalmia-associated transcription factor (MITF). The main signalling pathway in pigmentation involves melanocortin 1 receptor (MC1-R), which is activated by the $\alpha$-melanocyte-stimulating hormone $(\alpha-\mathrm{MSH})$ or adrenocorticotropic hormone (ACTH), which are products of proopiomelanocortin (POMC). MC1-R increases $3^{\prime}, 5^{\prime}$-cyclic adenosine monophosphate (cAMP) synthesis by activating adenylate cyclase. PKA, activated by cAMP, phosphorylates CREB, which then acts as a transcription factor 
of MITF (Figure 1) [4]. MITF is a basic helix-loop-helix leucine zipper that regulates the expression of melanogenic enzymes (tyrosinase, TYRP1 and TYRP2) and melanosome structural proteins (MART-1 and PMEL17) [5]. Previous studies have reported that melanocytes with a lower melanin content synthesise tyrosinase (TYR) more slowly and degrade it more quickly than melanocytes with a higher melanin content [6].

Table 1. Main activators of the melanogenesis pathways.

\begin{tabular}{lcc}
\hline $\begin{array}{l}\text { Key Signalling Pathways in } \\
\text { Melanogenesis }\end{array}$ & Activators & References \\
\hline MC1-R & $\alpha$-MSH, ACTH & {$[4-6]$} \\
SCF-c-KIT receptor tyrosine kinase & SCF & {$[3,7,8]$} \\
Protein kinase C-dependent signalling & DAG & {$[9,10]$} \\
Endothelin pathway & ETs & {$[11-13]$} \\
H1 and H2 receptors & H1, H2 & {$[14-16]$} \\
Keratinocyte-derived paracrine factors & IL-18, IL-33, GM-CSF, PGE2, PGF2 $\alpha$ & {$[17]$} \\
Fibroblast-derived paracrine factors & IL-33, PGE2, PGF2 $\alpha$ & {$[17]$} \\
\hline
\end{tabular}

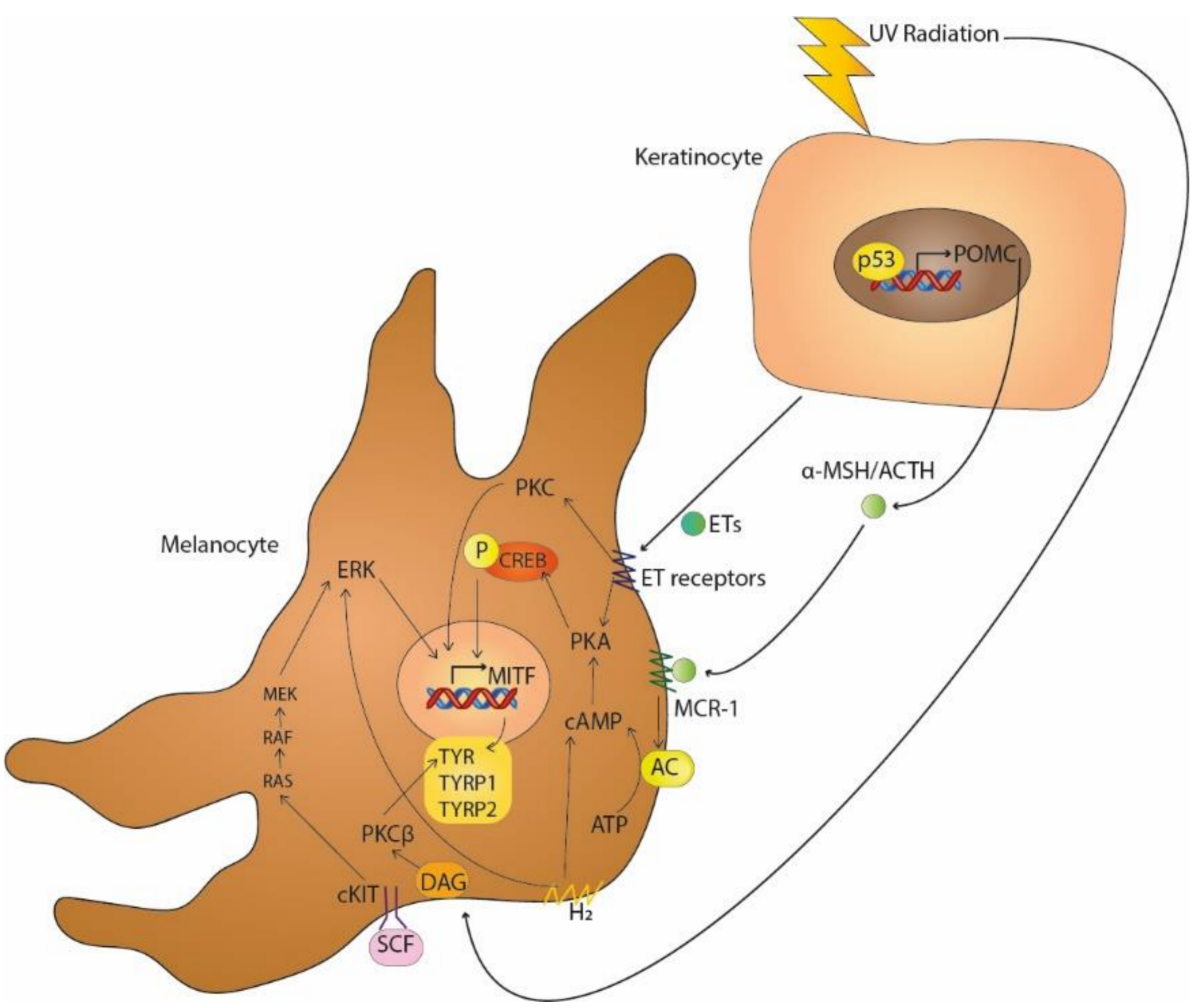

Figure 1. UV-induced melanogenesis by the secretion of $\alpha$-MSH/ACTH and ETs by keratinocytes activating MCR-1 and G protein-coupled ETs receptors, respectively, and by the induction of DAG on melanocytes membranes. Paracrine pathways, such as SCF-c-KIT receptor tyrosine kinase and $\mathrm{H}_{2}$ receptors, also induce melanogenesis.

The SCF-c-KIT receptor tyrosine kinase pathway is also involved in pigmentation. Stem cell factor (SCF), a paracrine factor located in fibroblasts, binds to its tyrosine kinase receptor c-KIT, which is produced by melanocytes, leads to the activation of the Ras-MAP kinase signalling pathway and the regulation of MITF by phosphorylation $[7,8]$.

Protein kinase $\mathrm{C}$ (PKC)-dependent signalling regulates melanogenesis by activating the PKC $\beta$ isoform via calcium and diacylglycerol (DAG), its endogenous activator. UV radiation (UVR) induces DAG formation in melanocyte membranes, causing its translocation from the cytoplasm to the membrane, where it upregulates $P K C \beta$, which then phosphorylates and activates tyrosinase. The receptor for activated C-kinase (RACK) controls the 
translocation of PKC isoforms to specific cellular compartments. The translocation of the PKA/RACK complex to the melanosome membrane leads to tyrosinase activation in human melanocytes [9]. Furthermore, the MITF-M isoform has been proposed as a key transcription factor for PKC $\beta$, linking PKC- and cAMP-dependent signalling in the regulation of melanogenesis [10].

$\mathrm{ET}_{\mathrm{A}}$ and $\mathrm{ET}_{\mathrm{B}}$ are endothelin (ET) receptors belonging to the $\mathrm{G}$ protein-coupled receptor family. Keratinocytes exposed to UVB radiation and melanocytes secrete ETs that have a high affinity for $\mathrm{ET}_{\mathrm{A}}$ and $\mathrm{ET}_{\mathrm{B}}$. ET-induced signalling dominates the activation of PKC through a specific ET receptor. This linkage activates PKC and PKA and leads to the increase in cAMP levels, thus increasing tyrosinase activity [11]. Moreover, endothelin-1 (ET-1), released by microvascular endothelial cells, increases melanogenesis through the phosphorylation of MITF and the increase in tyrosinase and dopachrome tautomerase levels. The activation of $\mathrm{ET}_{\mathrm{B}}$ and the extracellular signal-regulated kinase (ERK)1/2 and p38 MAP kinases by endothelin induces melanogenesis [12]. Pigmentation can be stimulated or inhibited via the ET receptor by chemicals. $\beta$-cryptoxanthin and fucoxanthin can inhibit melanogenesis via the ET receptor and other receptors by reducing the phosphorylation of CREB, whereas sphingosylphosphorylcholine, vitamin D3 and kappa-elastin can stimulate melanogenesis via the ET receptor and c-KIT [13].

The $\mathrm{H}_{1}$ and $\mathrm{H}_{2}$ histamine receptors occur on the surfaces of human melanocytes and melanoma cells. The accumulation of cAMP and the subsequent activation of PKA are induced via the $\mathrm{H}_{2}$ receptor, which activates ERK, CREB and Akt to stimulate melanogenesis [14]. Furthermore, it has been reported that the $\mathrm{H}_{2}$ receptor-mediated expression of growth-differentiation factor 15 (GDF-15) could be involved in histamine-induced melanogenesis $[15,16]$.

Hyperpigmentation is common after inflammation, although the mechanisms involved are not clear. Keratinocyte-derived paracrine factors such as interleukin (IL)-18, IL-33, granulocyte-macrophage colony-stimulating factor (GM-CSF), prostaglandin E2 and prostaglandin F2 $\alpha$ stimulate melanogenesis, while tumour necrosis factor (TNF), IL-6 and IL-1 $\alpha$ can inhibit melanogenesis. Fibroblasts also secrete paracrine factors that can induce melanogenesis, such as IL-33, prostaglandin E2 and prostaglandin F2 $\alpha$, as well as inhibitors of melanogenesis, such as TNF and IL-6 [17].

Tyrosinase is an oxidase enzyme that is fundamental in melanogenesis through its role in the hydroxylation of tyrosine to dihydroxyphenylalanine (DOPA) and the subsequent oxidation of DOPA to DOPA quinone. Two types of melanin are synthesised in melanogenesis: eumelanin, an insoluble polymer characterised by a brownish black colour; and pheomelanin, a reddish yellow soluble polymer. TRP1 and TRP2 are required for eumelanin synthesis from DOPA chrome which is produced by the action of tyrosinase on DOPA quinone, while pheomelanin synthesis from DOPA quinone requires the presence of sulphur derivates [18].

Eumelanin and pheomelanin bind to cations, anions and drugs, among other things, providing protection to melanocytes [3].

\section{Key Pathways in Melasma}

Melasma is a skin disorder that mainly affects the face and is caused by hyperpigmentation resulting from the increased accumulation of melanin in the epidermis. It can be induced through different mechanisms, which are heterogeneous in different individuals and ethnic groups [19]. Melasma is more common in women of reproductive age and in females with Fitzpatrick skin types III-IV, corresponding to European and North African Mediterranean populations [20].

Several treatment options are currently available, but none of them are effective or work fast enough. Oral medications and dietary supplements can be used to treat melasma, although the most important ways of managing melasma are the use of sun protection and topical agents [21]. 


\subsection{Ultraviolet Light}

It is well known that the main inducer of melanogenesis is ultraviolet radiation (UVR). In keratinocytes and the photoreceptor cells located in the external layer of the epidermis, different paracrine factors such as fibroblast growth factor (bFGF), nerve growth factor (NFG), ET-1 and POMC-derived peptides, such as MSH, ACTH and beta-endorphin, are activated by UVR, starting the main signalling pathway of melanogenesis [19]. UVR can induce and activate p53 on melanocytes, a tumour suppressor protein and transcription factor that upregulates tyrosinase mRNA and protein expression [22]. Furthermore, the UVR-mediated activation of p38, a stress-response protein, activates the transcription factor upstream stimulatory factor 1 (USF-1), which induces the transcription of tyrosinase [23]. Melanogenesis can be stimulated by the binding of $\alpha-\mathrm{MSH}$ to its receptor, MC1-R, promoting the synthesis of more eumelanin than pheomelanin and increasing tyrosinase activity [24]. Moreover, $\alpha-\mathrm{MSH}$ induces the proliferation of melanocytes [25]. UVR has been found to decrease levels of bone morphogenetic proteins (BMPs) [9].

UVR is divided into different ranges of functional wavelengths. UVC has the shortest wavelengths $(<280 \mathrm{~nm})$, which are excluded by the Earth's atmosphere. UVB has wavelengths (280-320 nm) that overlap with the absorption spectrum of DNA; therefore, it can cause damage associated with mutagenesis and tumorigenesis. Lastly, UVA (320-380 nm), which is not absorbed by DNA, can generate oxidative stress by producing intracellular reactive oxygen species (ROS) via photochemical reactions [26]. By the formation of ROS and melanin degradation products on melanocytes by UV light, cyclobutane pyrimidine dimers (CPDs) are produced by chemiexcitation and energy transfer. Cytosine-containing CPDs are included in this group, which initiate mutations of cytosine in thymine [27].

Different types of pigmentation can result from UVR. Immediate pigmentation, induced by UVA, is a transitory darkening of the skin that is produced by the oxidation of melanin and the redistribution of melanosomes to the upper epidermal layers. This pigmentation occurs a few minutes after exposure, but disappears minutes or days later, making it non-photoprotective. UVA can also induce persistent pigmentation that is easier to observe in individuals with dark skin compared to fair-skinned people. Delayed pigmentation, mainly by UVA and UVB, occurs 3-4 days after exposure to UVR and persists for weeks. It is caused by an increase in the levels of epidermal melanin, particularly eumelanin, providing photoprotection against DNA damage and mutations $[4,28,29]$.

\subsection{Genetics}

Melasma is caused by different exposure factors affecting genetically predisposed individuals. Thus, genetics are one of the most important causes of hyperpigmentation, as demonstrated by its occurrence within families (40-60\%) [30,31]. Almost 279 genes are involved in the development of melasma [16,32].

\subsection{Sex Hormones}

Oestrogen and progesterone are involved in hyperpigmentation, which sometimes appears during the use of oral contraceptives, pregnancy and in post-pubertal women. Several studies have shown an increased expression of oestrogen receptors in the dermis and progesterone receptors in the epidermis of hyperpigmented skin, suggesting a possible role of these hormones in the pathogenesis of melasma [33,34]. During the third trimester of pregnancy, the stimuli for melanogenesis increase, with sex steroids only inducing melasma in synergy with UVB [35].

In melanocytes and keratinocytes, the binding of oestrogen to its receptors can activate the tyrosinase and MITF pathways. Sex steroids increase the transcription of the DCT and TYR genes, thereby promoting melanogenesis in normal human melanocytes. Other studies have shown an oestrogen-induced increase in the mRNA expression of tyrosinase, TYRP1 and TYRP2, as well as increased activity of tyrosinase in normal human melanocytes [36,37]. The oestrogen-mediated upregulation of PDZ domain-containing 
protein (PDZK1) stimulates melanosome transfer to melanocytes and increases MITF and TYR expression in melanocytes [38].

While female sex steroids can have an important role in hyperpigmentation, male hormones appear not to have any role. UV radiation is the main factor for melanogenesis in men and interestingly, mustard oil can be another factor for hyperpigmentation in men in India, where it is used for hair growth and as an emollient [39]. Moreover, finasteride, an anti-androgen, might cause melasma in men [40].

\subsection{Wnt Signalling Pathway}

Wnt signalling plays a critical role in melanocyte development, melanogenesis and dendritogenesis [31]. The presence of Wnt ligands prevents $\beta$-catechin degradation, which stimulates MITF. WIF-1 is an important secreted antagonist of Wnt signalling. It inhibits Wnt signalling by preventing the binding of the ligands to their cell surface receptors [7]. WIF-1 downregulation occurs in dermal fibroblasts and epidermal keratinocytes of melasma lesions, stimulating the melanogenesis and melanosome transfer. Although WIF-1 is not expressed in melanocytes [41], one study has reported the upregulation of WIF-1 in melasma skin lesions [32].

WIF-1 expression does not change after UV radiation. Thus, melanogenesis can be induced via the Wnt signalling pathway independently of UVR [40]. Wnt inhibitors, such as DKK1 agonists, can be used to act on the fibroblast-secreted factors and reduce the hyperpigmentation caused by Wnt signalling [42,43].

\section{Treatments and Future Perspectives}

Hydroquinone $(\mathrm{HQ})$ monotherapy and triple combination cream are currently the most effective treatments for melasma despite the availability of different treatments (Table 2).

Table 2. Current treatments in melasma.

\begin{tabular}{|c|c|c|c|}
\hline \multicolumn{2}{|c|}{ Current Treatments } & Targets & References \\
\hline $\begin{array}{c}\text { Phenolic } \\
\text { compounds }\end{array}$ & $\begin{array}{l}\text { Hydroquinone } \\
\text { Glabridin }\end{array}$ & Tyrosinase inhibitor & $\begin{array}{c}{[44-48]} \\
{[17]}\end{array}$ \\
\hline \multirow{5}{*}{$\begin{array}{l}\text { Non-phenolic } \\
\text { compounds }\end{array}$} & $\begin{array}{l}\text { Arbutin } \\
\text { Deoxyarbutin } \\
\text { Kojic acid } \\
\text { Azelaic acid }\end{array}$ & Tyrosinase inhibitor & $\begin{array}{l}{[49-51]} \\
{[52-54]} \\
{[55-58]} \\
{[48,59]}\end{array}$ \\
\hline & Vitamin C & Tyrosinase inhibitor & [60-65] \\
\hline & $\begin{array}{l}\text { Liquorice } \\
\text { compounds }\end{array}$ & $\begin{array}{l}\text { Melanin dispersion and epidermal } \\
\text { melanin removal }\end{array}$ & {$[64,66,67]$} \\
\hline & Curcumoid & $\begin{array}{l}\alpha \mathrm{MSH} \text {-stimulated melanogenesis } \\
\text { suppression and inhibition of } \\
\text { melanosomes maturation }\end{array}$ & [68] \\
\hline & Retinoids & $\begin{array}{c}\text { Multiple targets (e.g., reduction in } \\
\text { TYR transcription) }\end{array}$ & {$[69,70]$} \\
\hline \multicolumn{2}{|c|}{ Triple combination cream } & Multiple targets & {$[71,72]$} \\
\hline \multicolumn{2}{|c|}{ Chemical peelings } & Melanin removal & [73] \\
\hline \multicolumn{2}{|c|}{ Laser and light therapies } & Melanin removal & {$[54,74-76]$} \\
\hline \multicolumn{2}{|c|}{ Oral treatments } & Unknown & [77-79] \\
\hline
\end{tabular}

Although there is a wide variety of treatments for melasma, there is still a need to establish new and improved therapies with a lower risk of side effects for melasma patients. Society is increasingly looking for natural treatments to minimise negative health effects. 


\subsection{Phenolic and Non-Phenolic Compounds}

Topical agents that act as tyrosinase inhibitors are the gold standard treatment for melasma. HQ is one of the most effective treatments, but its use is limited due to its cytotoxic activity and side effects such as irritation, erythema, irritant and allergic contact dermatitis, and amelanosis [44]. HQ inhibits the enzymatic oxidation of tyrosine to DOPA and suppresses other melanocytic processes $[45,46]$. It also induces ROS generation, causing the oxidative damage of membrane lipids and proteins (including tyrosinase) [47].

Arbutin, a natural tyrosinase inhibitor and HQ derivative, has been used in the treatment of melasma in combination with lasers or ellagic acid, as well as in hydrogel masks, all without undesirable side effects, thus demonstrating less toxicity than HQ [48,49]. It competitively and reversibly binds to tyrosinase without affecting the mRNA transcription of tyrosinase [50]. Deoxyarbutin, a synthetic derivative of arbutin, is a safer and effective skin-lightening agent, with similar inhibitory effects on tyrosinase activity as those of $\mathrm{HQ}$ and arbutin [51-54].

Kojic acid is a hydrophilic fungal metabolite that inhibits the catecholase activity of tyrosinase and has antioxidant activity $[55,56]$. It is commonly used in the treatment of melasma, especially in Asia and Japan, but can cause irritant contact dermatitis at high concentrations [57]. Studies have reported that kojic acid has limited efficacy as a monotherapy, producing better results in combination therapies $[55,57]$. A recent multicentre study across 20 dermatology clinics/ambulatories showed satisfactory effects with changes in severity index after three months of treatment [58].

Azelaic acid is a saturated dicarboxylic acid used as a treatment for skin pigmentation in several conditions such as acne and rosacea due to its anti-inflammatory property [48]. It was described that azelaic acid may directly or indirectly inhibit tyrosinase through the reduction in intracellular thioredoxin which inhibits tyrosinase by forming a bys-cysteinate inhibitors complex [59].

Vitamin C (ascorbic acid) can chelate copper ions, which are cofactors for melanogenesis. Vitamin $C$ and its derivatives suppress tyrosinase activity through cytoplasmic acidification [60]. In addition, vitamin $C$ has the ability to reduce o-quinones back to o-catechol, in the case of melanogenesis, reverting DOPA quinona to DOPA and preventing melanin synthesis [61]. However, its ability to decrease melanogenesis is lower than that of HQ $[62,63]$. Despite having low stability and fast oxidation and being ineffective as a monotherapy, vitamin $C$ is a good adjuvant, with its efficiency increases when combined with liquorice extracts [64]. Moreover, the combination of vitamin $C$ and vitamin E more significantly inhibits melanogenesis than vitamin $C$ alone [65].

Glabridin is the main component of the hydrophobic fraction of liquorice and can potentially inhibit tyrosinase activity [64]. Moreover, the other components of liquorice, such as liquiritin and isoliquiritin, can disperse melanin and remove epidermal melanin [66,67]. However, there is no clinical evidence of its efficacy in the treatment of melasma despite the fact that various depigmentation creams containing liquorice extracts are sold over the counter [56].

Calebin-A (CBA) is a natural curcuminoid analogue from turmeric root (Curcuma longa). Recent studies showed that CBA $(20 \mu \mathrm{M})$ significantly suppressed $\alpha \mathrm{MSH}$-stimulated melanogenesis in B16F10 mouse melanoma cells. CBA did not affect either intracellular tyrosinase activity or the direct activity of tyrosinase enzyme and did not affect intracellular $\alpha$-glucosidase activity. CBA increased the acidification of cellular organelles and inhibited the maturation of melanosomes by significantly reducing the number of mature melanosomes [68].

Retinoids target multiple signalling pathways in melanogenesis. They reduce tyrosinase transcription and melanin synthesis, causing rapid pigment loss through epidermopoiesis [69]. Retinoids are used in monotherapy or in combination to treat melasma and post-inflammatory hyperpigmentation [70]. 


\subsection{Other Therapies}

The triple combination cream (TCC) contains $4 \% \mathrm{HQ}, 0.05 \%$ tretinoin (retinoid) and $0.01 \%$ fluocinolone acetonide (fluorinated corticosteroid) [71]. Combination therapies have different side effects such as erythema, a burning sensation, a tingling sensation, and irritation, but these side effects are mild in most patients. The TCC can cause skin irritation and post-inflammatory hyperpigmentation depending on the colour of the skin [72].

Chemical peelings are used for several skin disorders despite causing skin irritation and post-inflammatory hyperpigmentation. Glycolic acid is the most widely used for chemical peelings, with salicylic acid representing a safer option for sensitive and dark phenotypes [73].

Laser and light resources/therapies should be used in resistant cases, although it can have adverse effects such as paradoxical hyperpigmentation, especially in high phototypes. Hence, depigmenting agents are required before and after treatment [56,74]. Intense pulsed light, fractional lasers and radiofrequency or pigment lasers are used in the treatment of melasma [75,76].

Oral treatments with systemic agents have emerged as potential therapies for melasma, such as tranexamic acid and plant-based supplements (e.g., polypodium leucotomos extract, carotenoids, and melatonin). Oral tranexamic acid is successfully used in Japan and seems to be more effective than topical therapy with tranexamic acid, although its mechanism of action is unknown $[77,78]$. Good results have been observed with the combination of tranexamic acid and laser irradiation [79]

\subsection{Future Treatments}

New therapies focusing on the multiple causes of hyperpigmentation, such as histamine synthesis, oestrogen upregulation, melanosome transfer and ROS generation, are being studied for the treatment of melasma since the targeting of melanin synthesis alone is not effective enough. Natural agents with a multimodal mechanism of action are being investigated due to their better safety profile compared to conventional drugs [80,81].

The following are examples of agents currently being assessed: resveratrol and $\mathrm{p}$ Coumaric acid (antioxidants), loratadine and zinc (antihistamines), and niacinamide and liquiritin (prevents melanosome transfer) [82-84].

The triple therapy, a combination of $\mathrm{HQ}$, an anti-oestrogen and a vascular endothelial growth factor inhibitor, seems to be the ideal skin-lightening agent [80].

\section{Conclusions and Perspectives}

MITF regulation is the key factor in melanogenesis and is therefore the main target for the induction of pigmentation in melasma. Although the main signalling pathways are known, new treatment should be developed to treat melasma due to the low efficacy or side effects of current treatments. Despite the importance of MITF regulation, other targets should be controlled on melasma treatment such as paracrine factors, the SCF-c-Kit and $\mathrm{H}_{2}$ receptor, and other UV-induced factors such as ETs secretion and DAG formation. Moreover, melasma generally affects women, so treatments focused on oestrogens have to be considered to obtain better results.

There is an increasing need on the part of society to use natural products as opposed to synthetic products. For this reason, researchers are increasingly focusing on this type of product in addition to providing a reduction in side effects. Natural products that disrupt melanogenesis are a good option for new treatments for melasma due to their safety compared to conventional ones.

Author Contributions: Writing, A.S.M., M.M. and M.P.V.; project management, M.M. and M.P.V.; project scope definition and financial support, J.C. All authors have read and agreed to the published version of the manuscript.

Funding: This research was funded by Doctorats industrials (2019), Agència de Gestió d'Ajuts Universitaris i de Recerca, Generalitat de Catalunya. 
Institutional Review Board Statement: Not applicable.

Informed Consent Statement: Not applicable.

Data Availability Statement: Not applicable.

Conflicts of Interest: The authors declare no conflict of interest.

\section{References}

1. Nordlund, J.J. The melanocyte and the epidermal melanin unit: An expanded concept. Dermatol. Clin. 2007, 25, 271-281. [CrossRef]

2. Wu, X.; Hammer, J.A. Melanosome transfer: It is best to give and receive. Curr. Opin. Cell. Biol. 2014, 29, 1-7. [CrossRef]

3. Costin, G.E.; Hearing, V.J. Human skin pigmentation: Melanocytes modulate skin color in response to stress. FASEB J. 2007, 21, 976-994. [CrossRef] [PubMed]

4. Videira, I.F.; Moura, D.F.; Magina, S. Mechanisms regulating melanogenesis. An. Bras. Dermatol. 2013, 88, 76-83. [CrossRef] [PubMed]

5. $\quad$ Ebanks, J.P.; Wickett, R.R.; Boissy, R.E. Mechanisms Regulating Skin Pigmentation: The Rise and Fall of Complexion Coloration. Int. J. Mol. Sci. 2009, 10, 4066-4087. [CrossRef]

6. Halaban, R.; Pomerantz, S.H.; Marshall, S.; Lambert, D.T.; Lerner, A.B. Regulation of Tyrosinase in Human Melanocytes Grown in Culture. J. Cell. Biol. 1983, 97, 480-488. [CrossRef]

7. Kawaguchi, M.; Suzuki, T. Melanogenesis and New Signaling Regulators for the Treatment of Melasma. In Melasma and Vitiligo in Brown Skin; Handog, E., Enriquez-Macarayo, M., Eds.; Springer: New Delhi, India, 2017; pp. 92-95.

8. Li, P.; Liu, L.; Chang, C.; Gao, R.; Leung, C. Silencing Stem Cell Factor Gene in Fibroblasts to Regulate Paracrine Factor Productions and Enhance c-Kit Expression in Melanocytes on Melanogenesis. Int. J. Mol. Sci. 2018, 19, 1475. [CrossRef] [PubMed]

9. Bae-Harboe, Y.C.; Park, H. Tyrosinase: A Central Regulatory Protein for Cutaneous Pigmentation. J. Investig. Dermatol. 2012, 132, 2678-2680. [CrossRef]

10. Park, H.; Wu, C.; Yonemoto, L.; Murphy-Smith, M.; Wu, H.; Stachur, C.M.; Gilchrest, B.A. MITF mediates cAMP-induced protein kinase C- $\beta$ expression in human melanocytes. Biochem. J. 2006, 578, 571-578. [CrossRef]

11. Imokawa, G.; Yada, Y.; Kimura, M. Signalling mechanisms of endothelin-induced mitogenesis and melanogenesis in human melanocytes. Biochem. J. 1996, 312, 305-312. [CrossRef]

12. Regazzetti, C.; De Donatis, G.M.; Ghorbel, H.H.; Cardot-leccia, N.; Ambrosetti, D.; Bahadoran, P.; Chignon-Sicard, B.; Lacour, J.; Ballotti, R.; Mahns, A.; et al. Endothelial Cells Promote Pigmentation through Endothelin Receptor B Activation. J. Investig. Dermatol. 2015, 135, 3096-3104. [CrossRef]

13. Lee, A.Y.; Noh, M. The regulation of epidermal melanogenesis via cAMP and/or PKC signaling pathways: Insights for the development of hypopigmenting agents. Arch. Pharm. Res. 2013, 36, 792-801. [CrossRef] [PubMed]

14. Reynolds, J.L.; Akhter, J.; Morris, D.L. In vitro effect of histamine and histamine H1 and H2 receptor antagonists on cellular proliferation of human malignant melanoma cell lines. Melanoma Res. 1996, 6, 95-99. [CrossRef] [PubMed]

15. Kim, N.H.; Lee, A.Y. Histamine effect on melanocyte proliferation and vitiliginous keratinocyte survival. Exp. Dermatol. 2010, 19, 1073-1079. [CrossRef] [PubMed]

16. Lee, H.J.; Park, M.K.; Lee, E.J.; Kim, Y.L.; Kim, H.J.; Kang, J.H.; Kim, H.M.; Lee, A.Y.; Lee, C.H. Histamine receptor 2-mediated growth-differentiation factor-15 expression is involved in histamine-induced melanogenesis. Int. J. Biochem. Cell Biol. 2012, 44, 2124-2128. [CrossRef]

17. Fu, C.; Chen, J.; Lu, J.; Yi, L.U.; Tong, X. Roles of inflammation factors in melanogenesis (Review). Mol. Med. Rep. 2020, 21, 1421-1430. [CrossRef]

18. Montaudié, H.; Bertolotto, C.; Ballotti, R.; Passeron, T. Fisiología del sistema pigmentario. Melanogénesis. EMC Dermatol. 2014, 48, 1-11. [CrossRef]

19. Lee, A.Y. An updated review of melasma pathogenesis. Dermatol. Sin. 2014, 32, 233-239. [CrossRef]

20. Rajanala, S.; Maymone, M.B.C.; Vashi, N.A. Melasma pathogenesis: A review of the latest research, pathological findings, and investigational therapies. Dermatol. Online J. 2019, 25. [CrossRef]

21. Zhou, L.L.; Baibergenova, A. Melasma: Systematic review of the systemic treatments. Int. J. Dermatol. 2017, 56, 902-908. [CrossRef] [PubMed]

22. Khlgatian, M.K.; Hadshiew, I.M.; Asawanonda, P.; Yaar, M.; Eller, M.S.; Fujita, M.; Norris, D.A.; Gilchrest, B.A. Tyrosinase gene expression is regulated by p53. J. Investig. Dermatol. 2002, 118, 126-132. [CrossRef]

23. Galibert, M.D.; Carreira, S.; Goding, C.R. The Usf-1 transcription factor is a novel target for the stress-responsive p38 kinase and mediates UV-induced Tyrosinase expression. EMBO J. 2001, 20, 5022-5031. [CrossRef] [PubMed]

24. Hunt, G.; Kyne, S.; Wakamatsu, K.; Ito, S.; Thody, A.J. Nle4DPhe7 $\alpha$-melanocyte-stimulating hormone increases the eumelanin:phaeomelanin ratio in cultured human melanocytes. J. Investig. Dermatol. 1995, 104, 83-85. [CrossRef] [PubMed]

25. Im, S.; Moro, O.; Peng, F.; Medrano, E.E.; Cornelius, J.; Babcock, G.; Nordlund, J.J.; Abdel-Malek, Z.A. Activation of the cyclic AMP pathway by $\alpha$-melanotropin mediates the response of human melanocytes to ultraviolet B radiation. Cancer Res. 1998, 58, 47-54. 
26. Ryter, S.W.; Hong, P.K.; Hoetzel, A.; Park, J.W.; Nakahira, K.; Wang, X.; Choi, A.M.K. Mechanisms of cell death in oxidative stress. Antiox. Redox Signal. 2007, 9, 49-89. [CrossRef]

27. Premi, S.; Wallisch, S.; Mano, C.M.; Weiner, A.B.; Bacchiocchi, A.; Wakamatsu, K.; Bechara, E.J.; Halaban, R.; Douki, T.; Brash, D.E. Photochemistry. Chemiexcitation of melanin derivatives induces DNA photoproducts long after UV exposure. Science 2015, 347, 842-847. [CrossRef]

28. Miyamura, Y.; Coelho, S.G.; Schlenz, K.; Batzer, J.; Smuda, C.; Choi, W.; Brenner, M.; Passeron, T.; Zhang, G.; Kolbe, L.; et al. The deceptive nature of UVA tanning versus the modest protective effects of UVB tanning on human skin. Pigment. Cell. Melanoma Res. 2011, 24, 136-147. [CrossRef] [PubMed]

29. Maddodi, N.; Jayanthy, A.; Setaluri, V. Shining light on skin pigmentation: The darker and the brighter side of effects of UV radiation. Photochem. Photobiol. 2012, 88, 1075-1082. [CrossRef]

30. Holmo, N.F.; Ramos, G.B.; Salomão, H.; Werneck, R.I.; Mira, M.T.; Miot, L.D.B.; Miot, H.A. Complex segregation analysis of facial melasma in Brazil: Evidence for a genetic susceptibility with a dominant pattern of segregation. Arch. Dermatol. Res. 2018, 310, 827-831. [CrossRef] [PubMed]

31. Passeron, T.; Picardo, M. Melasma, a photoaging disorder. Pigment. Cell. Melanoma Res. 2018, 31, 461-465. [CrossRef]

32. Kang, H.Y.; Suzuki, I.; Lee, D.J.; Ha, J.; Reiniche, P.; Aubert, J.; Deret, S.; Zugaj, D.; Voegel, J.J.; Ortonne, J.P. Transcriptional profiling shows altered expression of wnt pathway- and lipid metabolism-related genes as well as melanogenesis-related genes in melasma. J. Investig. Dermatol. 2011, 131, 1692-1700. [CrossRef]

33. Lieberman, R.; Moy, L. Estrogen receptor expression in melasma: Results from facial skin of affected patients. J. Drugs Dermatol. 2008, 7, 463-465. [PubMed]

34. Tamega Ade, A.; Miot, H.A.; Moço, N.P.; Silva, M.G.; Marques, M.E.; Miot, L.D. Gene and protein expression of oestrogen- $\beta$ and progesterone receptors in facial melasma and adjacent healthy skin in women. Int. J. Cosmet. Sci. 2015, 37, 222-228. [CrossRef] [PubMed]

35. Cario, M. How hormones may modulate human skin pigmentation in melasma: An in vitro perspective. Exp. Dermatol. 2019, 28, 709-718. [CrossRef]

36. Kippenberger, S.; Loitsch, S.; Solano, F.; Bernd, A.; Kaufmann, R. Quantification of tyrosinase, TRP-1, and TRP-2 transcripts in human melanocytes by reverse transcriptase-competitive multiplex PCR-Regulation by steroid hormones. J. Investig. Dermatol. 1998, 110, 364-367.

37. Cohen, P.R. Melasma treatment: A novel approach using a topical agent that contains an anti-estrogen and a vascular endothelial growth factor inhibitor. Med. Hypotheses 2017, 101, 1-5. [CrossRef]

38. Kim, N.H.; Cheong, K.A.; Lee, T.R.; Lee, A.Y. PDZK1 upregulation in estrogen-related hyperpigmentation in Melasma. J. Investig. Dermatol. 2012, 132, 2622-2631. [CrossRef]

39. Handa, S.; De, D.; Khullar, G.; Radotra, B.D.; Sachdeva, N. The clinicoaetiological, hormonal and histopathological characteristics of melasma in men. Clin. Exp. Dermatol. 2018, 43, 36-41. [CrossRef]

40. Famenini, S.; Gharavi, N.M.; Beynet, D.P. Finasteride associated melasma in a Caucasian male. J. Drugs Dermatol. 2014, 13, 484-486.

41. Kim, J.Y.; Lee, T.R.; Lee, A.Y. Reduced WIF-1 expression stimulates skin hyperpigmentation in patients with melasma. J. Investig. Derm. 2013, 133, 191-200. [CrossRef]

42. Yamaguchi, Y.; Passeron, T.; Watabe, H.; Yasumoto, K.I.; Rouzaud, F.; Hoashi, T.; Hearing, V.J. The effects of dickkopf 1 on gene expression and wnt signaling by melanocytes: Mechanisms underlying its suppression of melanocyte function and proliferation. J. Investig. Dermatol. 2007, 127, 1217-1225. [CrossRef] [PubMed]

43. Yamaguchi, Y.; Passeron, T.; Hoashi, T.; Watabe, H.; Rouzaud, F.; Yasumoto, K.; Hara, T.; Tohyama, C.; Katayama, I.; Miki, T.; et al. Dickkopf 1 (DKK1) regulates skin pigmentation and thickness by affecting Wnt/ $\beta$-catenin signaling in keratinocytes. FASEB J. 2008, 22, 1009-1020. [CrossRef]

44. Bandyopadhyay, D. Topical treatment of melasma. Indian J. Dermatol. 2009, 54, 303-309. [CrossRef] [PubMed]

45. Pillaiyar, T.; Manickam, M.; Namasivayam, V. Skin whitening agents: Medicinal chemistry perspective of tyrosinase inhibitors. J. Enzym. Inhib. Med. Chem. 2017, 32, 403-425. [CrossRef]

46. Baranska, A.; Shawket, A.; Jouve, M.; Baratin, M.; Malosse, C.; Voluzan, O.; Manh, T.P.V.; Fiore, F.; Bajénoff, M.; Benaroch, P.; et al. Unveiling skin macrophage dynamics explains both tattoo persistence and strenuous removal. J. Exp. Med. 2018, 215, 1115-1133. [CrossRef]

47. Jimbow, K.; Obata, H.; Pathak, M.A.; Fitzpatrick, T.B. Mechanism of depigmentation by hydroquinone. J. Investig. Dermatol. 1974, 62, 436-449. [CrossRef]

48. Mazurek, K.; Pierzchała, E. Comparison of efficacy of products containing azelaic acid in melasma treatment. J Cosmet. Dermatol. 2016, 15, 269-282. [CrossRef]

49. Ertam, I.; Mutlu, B.; Unal, I.; Alper, S.; Kivçak, B.; Ozer, O. Efficiency of ellagic acid and arbutin in melasma: A randomized, prospective, open-label study. J. Dermatol. 2008, 35, 570-574. [CrossRef] [PubMed]

50. Han, T.Y.; Son, I.P.; Jang, W.S.; Chang, H.S.; Kim, J.H.; Sim, Y.H.; Kim, D.H.; Kim, B.J.; Kim, M.N.; Lee, H.K.; et al. Efficacy of hydrogel mask with 2\% arbutin for melasma. Korean J. Dermatol. 2011, 49, 210-216.

51. Maeda, K.; Fukuda, M. Arbutin: Mechanism of its depigmenting action in human melanocyte culture. J. Pharmacol. Exp. Ther. 1996, 276, 765-769. [PubMed] 
52. Grimes, P.E. Melasma: Etiologic and Therapeutic Considerations. Arch. Dermatol. 1995, 131, 1453-1457. [CrossRef] [PubMed]

53. Parvez, S.; Kang, M.; Chung, H.S.; Cho, C.; Hong, M.C.; Shin, M.K.; Bae, H. Survey and mechanism of skin depigmenting and lightening agents. Phytother. Res. 2006, 20, 921-934. [CrossRef]

54. Picardo, M.; Carrera, M. New and Experimental Treatments of Cloasma and Other Hypermelanoses. Dermatol. Clin. 2007, 25, 353-362. [CrossRef]

55. Deo, K.S.; Dash, K.N.; Sharma, Y.K.; Virmani, N.C.; Oberai, C. Kojic acid vis-a-vis its combinations with hydroquinone and betamethasone valerate in melasma: A randomized, single blind, comparative study of efficacy and safety. Indian J. Dermatol. 2013, 58, 281-285. [CrossRef] [PubMed]

56. Küçük, Ö.S. Current treatment approaches for melasma. Bezm. Sci. 2018, 6, 54-62. [CrossRef]

57. Monteiro, R.C.; Kishore, N.; Bhat, R.M.; Sukumar, D.; Martis, J.; Ganesh, K. A comparative study of the efficacy of $4 \%$ hydroquinone vs $0.75 \%$ Kojic acid cream in the treatment of facial melasma. Indian J. Dermatol. 2013, 58, 157. [CrossRef] [PubMed]

58. Berardesca, E.; Rigoni, C.; Cantù, A.; Cameli, N.; Tedeschi, A.; Donne Dermatologhe Italia; Laureti, T. Effectiveness of a new cosmetic treatment for melasma. J. Cosmet. Dermatol. 2020, 19, 1684-1690. [CrossRef] [PubMed]

59. Schallreuter, K.; Wood, J. A possible mechanism of action for azelaic acid in the human epidermis. Arch. Derm. Res. 1990, 282, 168-171. [CrossRef] [PubMed]

60. Miao, F.; Su, M.Y.; Jiang, S.; Luo, L.F.; Shi, Y.; Lei, T.C. Intramelanocytic Acidification Plays a Role in the Antimelanogenic and Antioxidative Properties of Vitamin C and Its Derivatives. Oxid. Med. Cell Longev. 2019, 2019, 2084805. [CrossRef] [PubMed]

61. Huh, C.H.; Seo, K.I.; Park, J.Y.; Lim, J.G.; Eun, H.C.; Park, K.C. A randomized, double-blind, placebo-controlled trial of vitamin C iontophoresis in melasma. Dermatology 2003, 206, 316-320. [CrossRef]

62. Jiménez-Cervantes, C.; Solano, F.; Kobayashi, T.; Urabe, K.; Hearing, V.; Lozano, J. A new enzymatic function in the melanogenic pathway. The 5,6-dihydroxyindole-2-carboxylic acid oxidase activity of tyrosinase-related protein-1 (TRP1). J. Biol. Chem. 1994, 269, 17993-18000. [CrossRef]

63. Espinal-Perez, L.E.; Moncada, B.; Castanedo-Cazares, J.P. A double-blind randomized trial of $5 \%$ ascorbic acid vs. $4 \%$ hydroquinone in melasma. Int. J. Dermatol. 2004, 43, 604-607. [CrossRef] [PubMed]

64. Fu, B.; Li, H.; Wang, X.; Lee, F.S.C.; Cui, S. Isolation and identification of flavonoids in licorice and a study of their inhibitory effects on tyrosinase. J. Agric. Food Chem. 2005, 53, 7408-7414. [CrossRef]

65. Choi, Y.K.; Rho, Y.K.; Yoo, K.H.; Lim, Y.Y.; Li, K.; Kim, B.J.; Seo, S.J.; Kim, M.N.; Hong, C.K.; Kim, D.S. Effects of vitamin C vs. multivitamin on melanogenesis: Comparative study in vitro and in vivo. Pharmacol. Ther. 2019, 49, 218-226. [CrossRef]

66. Amer, M.; Metwalli, M. Topical liquiritin improves melasma. Int. J. Dermatol. 2000, 39, 299-301. [CrossRef] [PubMed]

67. Toossi, P.; Esmaili-Azad, M.; Saeedi, M. Evaluation of Licorice efficacy on melasma. Iran. J. Dermatol. $2013,16,118-119$.

68. Goenka, S.; Nagabhushanam, K.; Majeed, M.; Simon, S.R. Calebin-A, a Curcuminoid Analog Inhibits $\alpha$-MSH-Induced Melanogenesis in B16F10 Mouse Melanoma Cells. Cosmetics 2019, 6, 51. [CrossRef]

69. Romero, C.; Aberdam, E.; Larnier, C.; Ortonne, J.P. Retinoic acid as modulator of UVB-induced melanocyte differentiation. Involvement of the melanogenic enzymes expression. J. Cell. Sci. 1994, 107, 1095-1103. [CrossRef]

70. Wang, J.V.; Schoenberg, E.; Saedi, N. Bakuchiol as a Trendy Ingredient in Skincare: Recent Evidence. Skinmed 2019, 17, 188-189. [PubMed]

71. Banavase Channakeshavaiah, R.; Andanooru Chandrappa, N.K. Topical metformin in the treatment of melasma: A preliminary clinical trial. J. Cosmet. Derm. 2020, 19, 1161-1164. [CrossRef]

72. Pekmezci, E. A novel triple combination in treatment of melasma: Significant outcome with far less actives. J. Cosmet. Derm. 2019, 18, 1700-1704. [CrossRef] [PubMed]

73. Sarkar, R.; Garg, V.; Bansal, S.; Sethi, S.; Gupta, C. Comparative evaluation of efficacy and tolerability of glycolic acid, salicylic Mandelic acid, and Phytic acid combination peels in Melasma. Dermatol. Surg. 2016, 42, 384-391. [CrossRef] [PubMed]

74. Sadick, N.; Edison, B.L.; John, G.; Bohnert, K.L.; Green, B. An Advanced, Physician-Strength Retinol Peel Improves Signs of Aging and Acne Across a Range of Skin Types Including Melasma and Skin of Color. J. Drugs Dermatol. 2019, 18, 918-923. [PubMed]

75. McKesey, J.; Tovar-Garza, A.; Pandya, A.G. Melasma Treatment: An Evidence-Based Review. Am. J. Clin. Dermatol. 2020, 21, 173-225. [CrossRef] [PubMed]

76. Shah, S.D.; Aurangabadkar, S.J. Laser Toning in Melasma. J. Cutan. Aesthet. Surg. 2019, 12, 76-84. [CrossRef]

77. Del Rosario, E.; Florez-Pollack, S.; Zapata, L., Jr.; Hernandez, K.; Tovar-Garza, A.; Rodrigues, M.; Hynan, L.S.; Pandya, A.G. Randomized, placebo-controlled, double-blind study of oral tranexamic acid in the treatment of moderate-to-severe melasma. $J$. Am. Acad. Dermatol. 2018, 78, 363-369. [CrossRef]

78. Cho, H.H.; Choi, M.; Cho, S.; Lee, J.H. Role of oral tranexamic acid in melasma patients treated with IPL and low fluence QS Nd:YAG laser. J. Dermatol. Treat. 2013, 24, 292-296. [CrossRef]

79. Beyzaee, A.M.; Patil, A.; Goldust, M.; Moslemi, M.; Kazeminejad, A.; Rokni, G.R. Comparative Efficacy of Fractional CO2 Laser and Q-Switched Nd:YAG Laser in Combination Therapy with Tranexamic Acid in Refractory Melasma: Results of a Prospective Clinical Trial. Cosmetics 2021, 8, 37. [CrossRef]

80. Sarkar, R.; Bansal, A.; Ailawadi, P. Future therapies in melasma: What lies ahead? Indian J. Dermatol. Venereol. Leprol. 2020, 86, 8-17. [CrossRef] [PubMed]

81. Kim, K.; Huh, Y.; Lim, K.M. Anti-Pigmentary Natural Compounds and Their Mode of Action. Int. J. Mol. Sci. 2021, 22, 6206. [CrossRef] 
82. Boo, Y.C. Human skin lightening efficacy of resveratrol and its analogs: From in vitro studies to cosmetic applications. Antioxidants 2019, 8, 332. [CrossRef] [PubMed]

83. Boo, Y.C. p-coumaric acid as an active ingredient in cosmetics: A review focusing on its antimelanogenic effects. Antioxidants 2019, 8, 275. [CrossRef] [PubMed]

84. Moon, H.R.; Jo, S.Y.; Kim, H.T.; Lee, W.J.; Won, C.H.; Lee, M.W.; Choi, J.H.; Chang, S.E. Loratadine, an H 1 antihistamine, inhibits melanogenesis in human melanocytes. BioMed Res. Int. 2019, 2019, 5971546. [CrossRef] [PubMed] 